\title{
Comparative Analysis of Regional versus General Anesthesia
}

\author{
Luisa Mason ${ }^{1}$ and Dr. Tiffany Jackman ${ }^{1}$ \\ ${ }^{1}$ University of West Florida, Pensacola, Florida, United States \\ DOI: https://doi.org/10.47611/jsr.v9i2.792
}

\section{$\underline{\text { ABSTRACT }}$}

The administration of regional or general anesthesia is dependent upon many factors to help reduce complications and improve patient outcomes after surgery. In this comparative analysis, the advantages and disadvantages of both types of anesthesia as well as their respective contraindications are reviewed. Both regional and general anesthetics come with adverse effects including morbidity/mortality, and a certain threshold that warrants a type of anesthesia suitable for a surgical procedure. Although there are risks associated with both, certain patient populations may be at higher risk of complications including the elderly, severely ill, and individuals with specific medical conditions. A review of current literature advises the following factors to be examined prior to choosing an anesthesia method most appropriate for the patient including: body mass index (BMI), medical history, age, current medications, fasting time, alcohol/drug intake, pharmaceutical drug use, dental work and airway inspection, as well as neck flexibility and head extension. The research suggests that the patient be fully informed of the risks and benefits of both regional and general anesthesia, as well as taking part in the decision-making process.

\section{Introduction}

The administration of regional or general anesthesia is dependent upon many factors to help reduce complications and improve patient outcomes after surgery. While general anesthesia is performed to induce a loss of consciousness, regional anesthesia is used to numb a specific portion of the body. Regional anesthesia includes: spinal anesthesia, epidural anesthesia, and nerve blocks (Torpy, Lynm, \& Golub, 2011).

Anesthesia has been around for over a hundred years, Dr. Morton performed the first successful surgical procedure using anesthesia in 1846 (Robinson \& Toledo, 2012). Since then, many types of anesthesia were developed using many different drugs. William Halsted, founder of the John Hopkins School of Medicine, first used cocaine as a nerve block during surgery in 1884 (Redman, 2011). Nowadays, propofol is commonly used for general anesthesia. However, for regional anesthesia there are a variety of different drugs used for each subtype of regional anesthesia such as ropivacaine (Thompson, 2010). Each drug that is used in anesthesia comes with its own side-effects, making it even more important that the patient be well informed prior to a procedure. The goal for this research was to compare the differing types of anesthesia and to determine whether general or regional anesthesia was a safer option. 


\section{Methods}

The research plan included a review of the most recent peer-reviewed articles from journals dated between 2016 through 2019 to determine the side-effects, indications, and contraindications to both regional and general anesthesia. The projected outcome expected that regional anesthesia would have fewer risks than general anesthesia. The data was compiled by outlining the advantages, disadvantages, side-effects, as well as contraindications and indications of both types of anesthesia. Peer-reviewed journal articles were chosen using the following:

1. Databases: Pubmed, National Institute of Health (NIH), and Google Scholar

2. Keywords: General Anesthesia, Regional Anesthesia, Contraindications, and Complications

3. Inclusion/Exclusion: Scholarly Peer Review within the last three years

The expectation of this research assumed that regional would be a safer method of anesthesia with less side-effects.

\section{Results}

The literature advises several factors to be examined prior to choosing a anesthesia method most appropriate for the patient including: body mass index (BMI), medical history, age, current medications, fasting time, alcohol/drug intake, pharmaceutical drug use, dental work and airway inspection, neck flexibility and head extension. As noted in Table 1, both regional and general anesthesia come with respective advantages and disadvantages that should be taken into consideration before a procedure. Although predictions hypothesized that regional anesthesia is safer, the literature conceded that both have equal risks and the decision to use either was based on multiple factors.

With modern advances in medications, monitoring technology, and safety systems, as well as highly educated anesthesia providers, the risk caused by anesthesia to a patient undergoing routine surgery is extremely remote. Mortality attributable to general anesthesia is said to occur at rates of less than 1:100,000. Minor adverse events occur at more frequent rates, even in previously healthy patients Newman, 2018). 
Table 1. Side-by-side Comparison of Regional Versus General Anesthesia

\begin{tabular}{|c|c|c|c|c|c|}
\hline Type & Advantages & Disadvantages & Side Effects & Contraindications & Indications \\
\hline $\begin{array}{l}\text { Re- } \\
\text { gional }\end{array}$ & $\begin{array}{l}\text { Less nausea } \\
\text { Less vomiting } \\
\text { Less blood loss } \\
\text { Less risk of in- } \\
\text { fection and } \\
\text { pneumonia } \\
\text { Optional post-op } \\
\text { pain relief }\end{array}$ & $\begin{array}{l}\text { Time consum- } \\
\text { ing (sciatic } \\
\text { and femoral } \\
\text { blocks take } \\
15-30 \text { minutes } \\
\text { to be effec- } \\
\text { tive) } \\
\text { Failure rate is } \\
5 \% \\
\text { Anesthesia } \\
\text { provider must } \\
\text { have adequate } \\
\text { training }\end{array}$ & $\begin{array}{l}\text { Hypovolemia (increase in } \\
\text { blood volume) } \\
\text { Indeterminate neurologic } \\
\text { disease } \\
\text { Coagulopathy } \\
\text { Increased intracranial pres- } \\
\text { sure } \\
\text { Direct needle trauma } \\
\text { Abscess } \\
\text { Meningitis } \\
\text { Vertebral canal hematoma } \\
\text { Spinal cord ischemia } \\
\text { Cauda equina syndrome } \\
\text { (spinal cord damage) } \\
\text { Arachnoiditis (inflamma- } \\
\text { tion of spinal sheath) } \\
\text { Peripheral nerve injury } \\
\text { Cardiovascular collapse } \\
\text { Shivering } \\
\text { Transient mild hearing im- } \\
\text { pairment } \\
\text { Urinary retention (New } \\
\text { York School of Regional } \\
\text { Anesthesia, 2019) } \\
\text { Headache } \\
\text { Skin reaction or itch } \\
\text { Infection } \\
\text { Nerve damage } \\
\text { Paralysis } \\
\text { Respiratory failure } \\
\text { Pain } \\
\text { Numbness } \\
\text { Seizures } \\
\text { Reduced muscle control }\end{array}$ & $\begin{array}{l}\text { Infection at site or } \\
\text { sepsis } \\
\text { Patient refusal or is } \\
\text { uncooperative } \\
\text { Low blood pres- } \\
\text { sure } \\
\text { Allergy to local an- } \\
\text { esthesia } \\
\text { Anticoagulation } \\
\text { Preexisting periph- } \\
\text { eral neuropathy } \\
\text { Abnormal anatomy } \\
\text { (OpenAnesthesia, } \\
\text { 2019) }\end{array}$ & $\begin{array}{l}\text { Conditions } \\
\text { which re- } \\
\text { gional anes- } \\
\text { thesia is pre- } \\
\text { ferred: } \\
\text { Diabetic } \\
\text { Ischemia } \\
\text { Respiratory } \\
\text { diseases } \\
\text { Cardiac fail- } \\
\text { ure }\end{array}$ \\
\hline
\end{tabular}




\begin{tabular}{|c|c|c|c|c|c|}
\hline & & & $\begin{array}{l}\text { Death (American Society } \\
\text { of Anesthesiology, 2015) }\end{array}$ & & \\
\hline General & $\begin{array}{l}\text { Reduces in- } \\
\text { traoperative pa- } \\
\text { tient awareness } \\
\text { and recall } \\
\text { Allows use of } \\
\text { muscle relaxants } \\
\text { Facilitates com- } \\
\text { plete control of } \\
\text { the airway, } \\
\text { breathing, and } \\
\text { circulation } \\
\text { Can be used in } \\
\text { cases of sensitiv- } \\
\text { ity to local anes- } \\
\text { thetic agent } \\
\text { Can be adminis- } \\
\text { tered without } \\
\text { moving the pa- } \\
\text { tient from the } \\
\text { supine position } \\
\text { Can be adapted } \\
\text { easily to proce- } \\
\text { dures of unpre- } \\
\text { dictable duration } \\
\text { or extent } \\
\text { Can be adminis- } \\
\text { tered rapidly and } \\
\text { is reversible }\end{array}$ & $\begin{array}{l}\text { Requires pre- } \\
\text { operative pa- } \\
\text { tient prepara- } \\
\text { tion } \\
\text { Requires in- } \\
\text { creased com- } \\
\text { plexity of care } \\
\text { and associated } \\
\text { costs } \\
\text { May induce } \\
\text { physiological } \\
\text { fluctuations } \\
\text { that require } \\
\text { active inter- } \\
\text { vention } \\
\text { May induce } \\
\text { malignant hy- } \\
\text { perthermia (le- } \\
\text { thal tempera- } \\
\text { ture rise, hy- } \\
\text { percarbia, } \\
\text { metabolic aci- } \\
\text { dosis, and hy- } \\
\text { perkalemia) }\end{array}$ & $\begin{array}{l}\text { Nausea/vomiting } \\
\text { Sore throat } \\
\text { Incisional site pain } \\
\text { Emergence delirium (in } \\
\text { children) (Adler, 2018) } \\
\text { Unintended intraoperative } \\
\text { awareness } \\
\text { Postoperative confusion } \\
\text { and memory loss (although } \\
\text { this is more common in the } \\
\text { elderly) } \\
\text { Dizziness } \\
\text { Difficulty passing urine } \\
\text { Bruising or soreness from } \\
\text { the IV drip } \\
\text { Shivering and feeling cold } \\
\text { Heart attack } \\
\text { Pneumonia } \\
\text { Stroke } \\
\text { Death (Newman, 2018) }\end{array}$ & $\begin{array}{l}\text { There are no abso- } \\
\text { lute contraindica- } \\
\text { tions to general an- } \\
\text { esthesia; however, } \\
\text { there are many rel- } \\
\text { ative contraindica- } \\
\text { tions. A preopera- } \\
\text { tive evaluation is } \\
\text { completed review- } \\
\text { ing patients': } \\
\text { medical comorbidi- } \\
\text { ties, } \\
\text { heart/lung/kidney } \\
\text { function, and } \\
\text { pregnancy/smoking } \\
\text { status (Smith \& } \\
\text { Goldman, 2018). } \\
\text { Conditions that in- } \\
\text { crease risks: } \\
\text { obstructive sleep } \\
\text { apnea } \\
\text { seizures } \\
\text { existing heart, kid- } \\
\text { ney or lung condi- } \\
\text { tions } \\
\text { high blood pressure } \\
\text { alcoholism } \\
\text { smoking } \\
\text { history of reactions } \\
\text { to anesthesia } \\
\text { medications that } \\
\text { can increase bleed- } \\
\text { ing } \\
\text { drug allergies }\end{array}$ & $\begin{array}{l}\text { Reduces in- } \\
\text { traoperative } \\
\text { awareness } \\
\text { Allows use of } \\
\text { muscle relax- } \\
\text { ants } \\
\text { Facilitates } \\
\text { complete con- } \\
\text { trol of the air- } \\
\text { way } \\
\text { Can be used } \\
\text { in cases of } \\
\text { sensitivity to } \\
\text { local anes- } \\
\text { thetic agent } \\
\text { Can be ad- } \\
\text { ministered } \\
\text { without mov- } \\
\text { ing the pa- } \\
\text { tient from the } \\
\text { supine posi- } \\
\text { tion } \\
\text { Can be } \\
\text { adapted easily } \\
\text { to procedures } \\
\text { of unpredicta- } \\
\text { ble duration } \\
\text { or extent } \\
\text { Can be ad- } \\
\text { ministered } \\
\text { rapidly and is } \\
\text { reversible } \\
\text { (Adler, 2018) }\end{array}$ \\
\hline
\end{tabular}




\begin{tabular}{|l|l|l|l|l|}
\hline & & & & diabetes \\
obesity or over- & \\
weight (Newman, & \\
$2018)$ & & \\
\hline
\end{tabular}

\section{Conclusion}

There are no absolute contraindications to general anesthesia. However, there are many relative contraindications. The research suggests that the patient be fully informed of the risks and benefits of both regional and general anesthesia, as well as taking part in the decision-making process. The patients who plan to go through general anesthesia should undergo preoperative evaluation by the anesthesia provider. This evaluation involves a review of the patient's medical comorbidities, heart/lung/kidney function, and pregnancy/smoking status. The patient's medical condition is maximized preoperatively if at all possible, meaning that any risk factors or possible complications are eliminated prior to the procedure (Smith \& Goldman, 2018). There was no evidence to suggest that anesthesia type influences postoperative delirium or mortality. Some studies suggested a small reduction in length of hospital stay with regional anesthesia; however, more research is needed to determine subsequent patient outcomes.

\section{Future Considerations}

There are many subcategories of regional anesthesia, including epidural, spinal, and nerve block. The advantages and disadvantages of regional anesthesia can be summarized when comparing it to general anesthesia, but there are still differences between the subcategories that should be considered when choosing regional anesthesia for a procedure. Future research will include a comparative analysis between types of regional anesthesia to further aid in the decisionmaking process when choosing an anesthesia for a procedure.

\section{References}

Adler, A. C. (2018). General Anesthesia. Medscape. Retrieved from https://emedicine.medscape.com/article/1271543-overview

National Clinical Guideline Centre (UK). (2011).The Management of Hip Fracture in Adults [Internet]. London: Royal College of Physicians (UK). (NICE Clinical Guidelines, No. 124.) 8, Regional (spinal or epidural) versus general anaesthesia. Available from: https://www.ncbi.nlm.nih.gov/books/NBK83023/

Newman, T. (2018). What to know about general anesthesia. Medical News Today. Retrieved from https://www.medicalnewstoday.com/articles/265592.php 
Patel, V., Champaneria, R., Dretzke, J., \& Yeung, J. (2018). Effect of regional versus general anaesthesia on postoperative delirium in elderly patients undergoing surgery for hip fracture: A systematic review. BMJ open, 8(12), e020757. doi:10.1136/bmjopen-2017-020757

Redman M. (2011). Cocaine: What is the Crack? A Brief History of the Use of Cocaine as an Anesthetic. Anesthesiology and pain medicine, 1(2), 95-97. doi:10.5812/kowsar.22287523.1890

Robinson, D. H., \& Toledo, A. H. (2012). Historical development of modern anesthesia. Journal of Investigative Surgery, 25(3), 141-149. https://doi.org/10.3109/08941939.2012.690328

Smith, G., and Goldman J. (2018). General Anesthesia for Surgeons. StatPearls [Internet]. Treasure Island (FL): StatPearls Publishing; 2018 Jan-. Available from: https://www.ncbi.nlm.nih.gov/books/NBK493199/

Thompson, C. (2010, April). Anaesthesia - an introduction. Retrieved from http://www.anaesthesia.med.usyd.edu.au/resources/lectures/anaesthesia_basics.htmlTorpy, J. M., Lynm, C., \& Golub R. M. (2011). Regional Anesthesia. JAMA. 306(7):781. doi:10.1001/jama.306.7.781 